\title{
Fuel selection in intestinal cells
}

\author{
BY PIERRE-HENRI DUÉE, BÉATRICE DARCY-VRILLON, \\ FRANÇOIS BLACHIER AND MARIE-THÉRÈSE MOREL \\ Institut National de la Recherche Agronomique, UEPSD \\ CRJ F-78352 Jouy-en-Josas Cedex, France
}

\section{Sélection de substrats énergétiques dans les cellules intestinales}

\begin{abstract}
RÉSUMÉ
Compte tenu de ses fonctions multiples, l'intestin, première cible de l'aliment, joue un rôle crucial dans le maintien de l'état de santé. Les fonctions d'hydrolyse et de transport assurées par les cellules intestinales différenciées, et d'une façon générale, l'intégrité des membranes intestinales nécessitent un métabolisme intense de certains nutriments, d'origine luminale et/ou vasculaire. La demande énergétique est, en effet, très élevée puisque la consommation intestinale d' $\mathrm{O}_{2}$ s'élève à $20-25 \%$ de la consommation totale de l'organisme. Parmi les nutriments, qui rendent compte de cette consommation énergétique élevée, le rôle de la glutamine a été démontré. Les raisons pour lesquelles cet acide aminé, prélevé du côté luminal (avec le glutamate et l'aspartate) comme du côté vasculaire est utilisé d'une façon privilégiée, sont évoquées (activité et affinité de la glutaminase ( $E C$ 3.5.1.2), décarboxylation incomplète de la glutamine conduisant à la génération de composés à trois carbones, interactions métaboliques avec les autres nutriments). Par ailleurs, le faible rôle énergétique dans l'intestin grêle du glucose et des acides gras à longue chaine est expliqué. Néanmoins, dans la partie distale de l'intestin (colon), les acides gras à courte chaine, et plus particulièrement, le butyrate, représentent des substrats énergétiques majeurs des cellules épithéliales. Enfin, les modifications du métabolisme énergétique des cellules intestinales en fonction de l'âge et de l'état pathologique sont abordées. L'adaptation du métabolisme énergétique de l'intestin grêle au cours du développement fait ainsi apparaître des voies métaboliques transitoires telles que la voie de la gluconéogenèse et de la cétogenèse.
\end{abstract}

The gastrointestinal tract is a site of high $\mathrm{O}_{2}$ uptake, the latter amounting to $20-25 \%$ of the whole-body $\mathrm{O}_{2}$ consumption, even in the post-absorptive or fasting state (Yen et al. 1989; Vaugelade et al. 1994). The consumption of a meal in humans as well as in animal models is generally accompanied by a rise in energy expenditure. In humans, half the enhanced $\mathrm{O}_{2}$ consumption occurs in splanchnic organs (Brundin \& Wahren, 1991). As demonstrated in animal models, this enhancement of intestinal $\mathrm{O}_{2}$ uptake is explained by an increase either in blood flow to the digestive organs or $\mathrm{O}_{2}$ extraction rate (Granger \& Norris, 1980; Sit \& Chou, 1984). This high energy demand of the gastrointestinal tract parallels a high fractional rate of protein synthesis linked to a rapid turnover rate of epithelial cells and a high rate of intracellular protein synthesis. 
Table 1. Contribution of nutrients to respiratory carbon dioxide in rat jejunum

$$
\text { (\% } \mathrm{CO}_{2} \text { yield) }
$$

(Experiments were performed with autoperfused jejunal segments of rats, as described in Windmueller \& Spaeth $(1978,1980)$. Post-absorptive animals were $16 \mathrm{~h}$-fasted and fed rats were perfused luminally with an Earle's balanced salt solution plus glucose $(70 \mathrm{mM})$ and nineteen L-amino acids $(0 \cdot 5-6.5 \mathrm{~mm}$ each) to simulate a meal)

\begin{tabular}{lcc}
\hline \hline & Post-absorptive state & Fed state \\
\hline Glutamine & 35 & $77^{*}$ \\
Ketone bodies & 50 & 7 \\
Glucose & 7 & 6 \\
Fatty acids & 3 & nd \\
\hline \hline
\end{tabular}

* With luminal glutamate and aspartate.

nd, Not determined.

Measurements based on arterial-venous differences across autoperfused segments of rat jejunum have shown that glutamine, glucose and ketone bodies are widely taken up by intestinal tissues (Windmueller \& Spaeth, 1974, 1978, 1980). Because glutamine and ketone bodies account for 35 and $50 \%$ respectively of the total $\mathrm{CO}_{2}$ produced, they represent the major oxidative substrates of the rat small intestine in post-absorptive conditions (Table 1). However, in fed rats, glutamine available both from the intestinal lumen (with glutamate and aspartate) and from the vascular bed provides the main source of energy for the intestinal tissues. Conversely, whatever the nutritional conditions, fatty acids and glucose do not represent significant energy sources for the gastrointestinal tissues even though glucose uptake by intestinal tissues is as high as that of glutamine (Windmueller \& Spaeth, 1978, 1980). These metabolic data were obtained with preparations containing different cell types. To explain why the gastrointestinal tissues use such a range of fuel substrates, it is necessary to examine simplified preparations based on a single cell type.

Investigating the metabolic capacities of epithelial cells which represent the predominant cell population in intestinal tissues confirms that glutamine is an important respiratory fuel for enterocytes or colonocytes (Watford et al. 1979; Roediger, 1982; Ardawi \& Newsholme, 1985; Ashy \& Ardawi, 1988; Fig. 1). However, these in vitro measurements also point to a high capacity for glucose oxidation, which conflicts with the in vivo observations. Moreover, cells isolated from the distal part of the gastrointestinal tract (colon) exhibit a high capacity for short-chain fatty acid oxidation, suggesting a variable metabolic response of intestinal cells according to their location. Thus, the main objective of the present review is to provide some information about the metabolic characteristics of intestinal cells and their adaptation.

\section{WHY INTESTINAL CELLS SELECT GLUTAMINE AS \\ A FUEL SUBSTRATE}

Glutamine is the main vehicle for the transfer of $N$ between muscle and splanchnic tissues (Souba, 1991). The first reaction in glutamine degradation is catalysed by a mitochondrial phosphate-dependent glutaminase (EC 3.5.1.2), whose activity is higher 


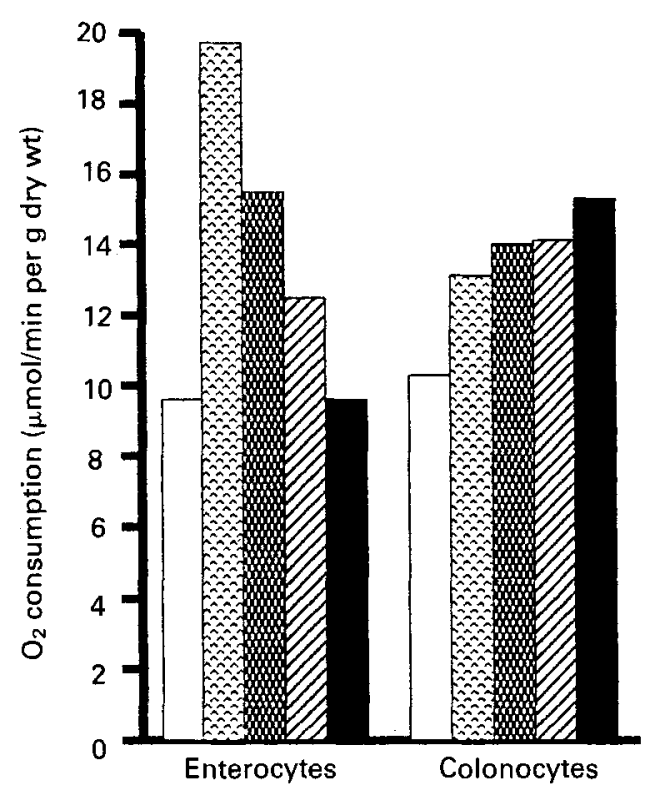

Fig. 1. Effects of added substrates on oxygen consumption rate of intestinal cells. Rates of $\mathrm{O}_{2}$ consumption were measured in rat enterocytes as described by Watford et al. (1979) and in rat colonocytes as described by

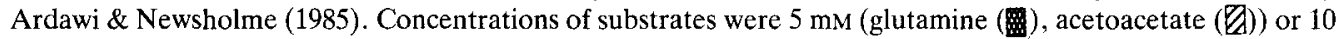

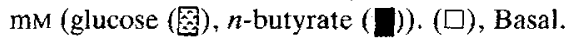

in the intestine than that in most other tissues (Newsholme \& Carrié, 1994). However, a slightly lower activity of glutaminase is found in the distal part of the intestine. Glutaminase activity is detected in mature epithelial cells from the villi as well as in rapidly-dividing cells from the crypts (Pinkus \& Windmueller, 1977). The apparent $K_{m}$ of glutaminase for glutamine is about $2.2 \mathrm{~mm}$ at $\mathrm{pH} 8 \cdot 1$, which is tenfold lower than that of the liver (Pinkus \& Windmueller, 1977). The high affinity of the intestinal enzyme, also, could explain the very low concentration of the amino acid found in the intestinal mucosa. Glutamate generated through glutaminase may be further metabolized via transamination reactions or by glutamate dehydrogenase $(E C$ 1.4.1.2). Since the activity of glutamate dehydrogenase is very low in intestinal mucosa, this suggests that glutamate is metabolized through the transaminase reactions leading to alanine and aspartate formation. Indeed, as demonstrated by Windmueller \& Spaeth (1980), glutamine-N is mainly recovered in $\mathrm{NH}_{3}$ and alanine $(65 \%)$, and also in citrulline $(28 \%)$.

$\mathrm{CO}_{2}$ production from glutamine is concentration-dependent in cells isolated from the jejunum or the colon of fed rats and may be saturated at a glutamine concentration several times those found in the blood or in the intestinal lumen (Kight \& Fleming, 1993). The large recovery of glutamine- $\mathrm{C}$ in $\mathrm{CO}_{2}$ (60\% from in vivo preparations), lactate, other organic acids and alanine suggests that an extensive but incomplete glutamine oxidation prevails in intestinal mucosa (Windmueller \& Spaeth, 1978, 1980). The fate of glutamine-C was recently followed in rat enterocytes by comparing the rate of ${ }^{14} \mathrm{CO}_{2}$ production from differentially labelled $\mathrm{L}-\left[{ }^{14} \mathrm{C}\right]$ glutamine (Watford, 1994). The 


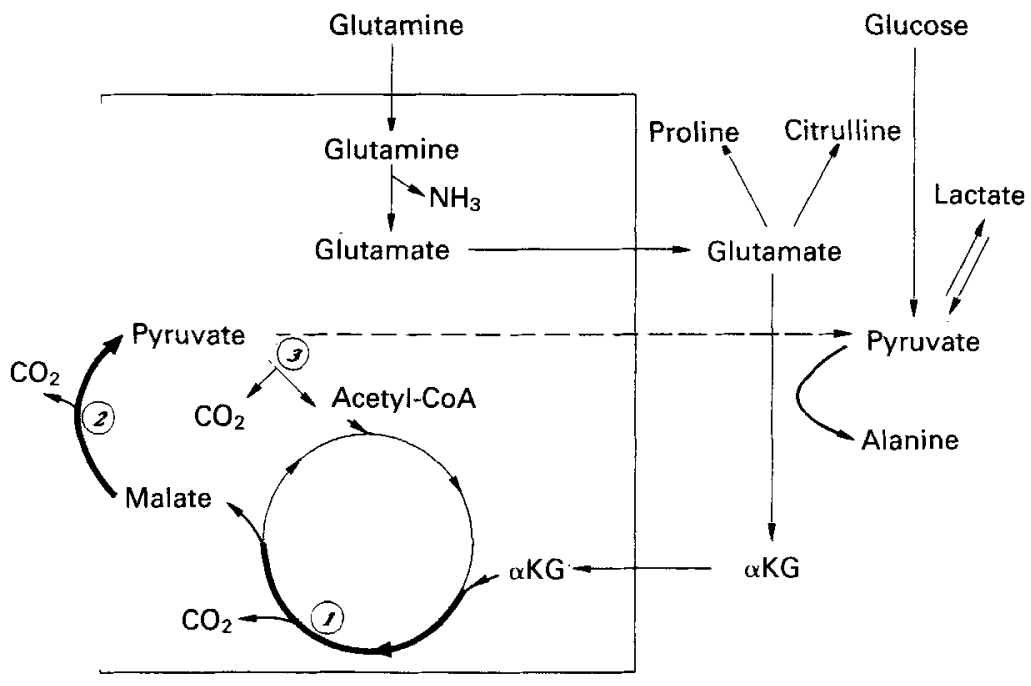

Fig. 2. A proposed scheme for the decarboxylation of glutamine in intestinal cells. The predominant steps in glutamine decarboxylation are those catalysed by $\alpha$-ketoglutarate $(\alpha \mathrm{KG})$ dehydrogenase $(E C 1.2 .4 .2 ; 1)$ and NAD $(\mathrm{P})^{+}$-dependent malic enzyme $(E C 1.1 .1 .38,1.1 .1 .40 ; 2)$. The pyruvate dehydrogenase $(E C 1.2 .4 .1)$ reaction (3) is not important in glutamine decarboxylation. $\mathrm{C}_{3}$ endproducts are alanine and lactate. (Adapted from Hanson \& Parsons, 1980; Mallet et al. 1986b; Watford, 1994.)

results indicate that glutamine undergoes two decarboxylations and that the labelled $\mathrm{C}_{3}$ endproduct is either alanine or lactate depending on the flux rate through the pyruvate pool. Glutamine metabolism has also been studied using the $\mathrm{CO}_{2}$ ratio technique (Mallet et al. $1986 a, b$ ). Calculations based on this technique estimate the probability that a molecule which enters the tricarboxylic acid cycle will either remain in the cycle for one complete turn or will leave and re-enter as acetyl-CoA. Calculations from succinate- $\mathrm{CO}_{2}$ ratio $\left({ }^{14} \mathrm{CO}_{2}\right.$ from $\left[1,4-{ }^{14} \mathrm{C}\right]$ succinate: ${ }^{14} \mathrm{CO}_{2}$ from $\left[2,3-{ }^{14} \mathrm{C}\right]$ succinate $)$ or from acetate$\mathrm{CO}_{2}$ ratio $\left({ }^{14} \mathrm{CO}_{2}\right.$ from $\left[1-{ }^{14} \mathrm{C}\right]$ acetate: ${ }^{14} \mathrm{CO}_{2}$ from $\left[2-{ }^{14} \mathrm{C}\right]$ acetate $)$ in the presence of glutamine predicts that glutamine molecules entering the tricarboxylic acid cycle have a low probability of remaining in the cycle for a complete turn (Mallet et al. 1986b; Fleming \& Kight, 1994). The first step of glutamine decarboxylation is presumably via the $\alpha$-ketoglutarate dehydrogenase ( $E C 1.2 .4 .2)$ reaction. Several enzymes could play a potential role in the second step of decarboxylation: phosphoenolpyruvate carboxykinase ( $E C$ 4.1.1.32; PEPCK) plus pyruvate kinase $(E C 2.7 .1 .40)$, malic enzyme $\left(\mathrm{NAD}(\mathrm{P})^{+}\right.$-dependent; $E C$ 1.1.1.38, 1.1.1.40) and oxaloacetate decarboxylase $(E C$ 4.1.1.3). Because the addition of 3-mercaptopicolinate, an inhibitor of PEPCK, has no effect on glutamine oxidation, PEPCK plus pyruvate kinase may play only a minor role in the second decarboxylation of glutamine- $\mathrm{C}$ and the generation of pyruvate and alanine (Hanson \& Parsons, 1977; Watford et al. 1979; Watford \& Tatro, 1989; Watford, 1994). Similarly, the step catalysed by oxaloacetate decarboxylase probably does not make a significant contribution to the decarboxylation of glutamine. This suggests that the mitochondrial $\mathrm{NAD}(\mathrm{P})^{+}$-dependent malic enzyme is the enzyme responsible for the second step of glutamine decarboxylation (Hanson \& Parsons, 1980), as proposed in Fig. 2. 
In enterocytes isolated from rat small intestine the presence of glucose does not generally modify the rate of glutamine utilization, but stimulates $\mathrm{CO}_{2}$ production from glutamine by $20-35 \%$; this reinforces the argument for glutamine as a major respiratory substrate for intestinal cells (Ashy \& Ardawi, 1988; Fleming \& Kight, 1994; Watford, 1994). Stimulation by glucose of intestinal glutamine metabolism and oxidation, also, has been demonstrated in other conditions (Weber et al. 1982; Rhoads et al. 1992). Indeed, glucose generates pyruvate which is used in the transamination of glutamate (Fig. 2). Moreover, in experiments on isolated enterocyte mitochondria, $\mathrm{O}_{2}$ consumption related to glutamine oxidation is significantly enhanced by the presence of malate (Evered \& Masola, 1984), suggesting that the entry of glutamine into the tricarboxylic acid cycle and/or the efflux of intermediates from the cycle may be stimulated by glucose metabolism (Fleming \& Kight, 1994). Under fasting conditions, a high capacity for glutamine oxidation is maintained in isolated enterocytes (Vaugelade et al. 1994), although glutaminase activity is slightly depressed (Newsholme \& Carrié, 1994). In contrast, glutamine oxidation is profoundly altered during fasting in isolated colonocytes (Firmansyah et al. 1989).

The overall balance of ATP and the acid-base balance for the metabolic processes occurring in the gut have been calculated recently (Jungas et al. 1992). The calculations based on a daily intake of $110 \mathrm{~g}$ protein by a human adult indicate that $80 \%$ of total $\mathrm{O}_{2}$ uptake of the human jejunum results from the oxidation of lumen and arterial glutamine, in addition to that of lumen glutamate and aspartate, which confirms previous data from Windmueller \& Spaeth (1980). The role of glutamine in the gastrointestinal tract is not limited to being a major energy source because it also provides amide- $\mathrm{N}$ for nucleotide synthesis and other $\mathrm{N}$ compounds (proline, citrulline). Dietary arginine, also, is highly metabolized during intestinal transport to provide urea, ornithine and citrulline but, unlike glutamine, arginine does not represent a significant energy source for the small intestine (Blachier et al. 1991a).

\section{WHY INTESTINAL CELLS DO NOT SELECT GLUCOSE AND FATTY ACIDS AS FUEL SUBSTRATES}

Although intestinal uptake of glucose seems to be high in rats in the post-absorptive state, glucose does not represent an important energy source in the mucosa (Windmueller \& Spaeth, 1978). This is true also in the fed state when lumen glucose is available (Windmueller \& Spaeth, 1980). Since the capacity for glucose oxidation is high in intestinal cells from fed rats (Watford et al. 1979; Fleming et al. 1991; Kight \& Fleming, 1993), this involves a rapid adaptation of glucose metabolism during glucose transport and absorption. Glucose oxidation corresponds to $\mathrm{CO}_{2}$ production (in the pyruvate dehydrogenase complex and tricarboxylic acid cycle). The pentose phosphate pathway contributes weakly to $\mathrm{CO}_{2}$ generation (Mallet et al. 1986a; Blachier et al. $1991 \mathrm{~b}$ ). Thus, the generation of pyruvate and its oxidation determines the rate of glucose oxidation. Because glycolysis is the main pathway of glucose metabolism, the generation of pyruvate from glucose has not been identified as a limiting step in glucose oxidation. The probability that pyruvate derived from glucose will be oxidized is high (Mallet et al. 1986a; Fleming \& Kight, 1994). Moreover, a stimulation of pyruvate dehydrogenase activity by the addition of dichloroacetate does not further increase glucose oxidation (Vidal et al. 1988). In contrast, the presence of glutamine profoundly reduces glucose 
oxidation without effect on glucose utilization (Watford et al. 1979; Kimura, 1987; Ashy \& Ardawi, 1988). This result is probably explained both by the diversion of pyruvate towards glutamate transamination (see p. 87) and by a direct effect of NADH generated by glutamine metabolism on the activity of pyruvate dehydrogenase complex (Fleming \& Kight, 1994). Pyruvate dehydrogenase activity and pyruvate oxidation, also, are profoundly depressed by the intramitochondrial generation of acetyl-CoA and NADH during fatty acid oxidation in enterocytes (Lamers \& Hülsmann, 1974; Vidal et al. 1988). Although the rate of fatty acid oxidation seems to be very low in enterocytes (see below), the latter probably gives rise to a rapid increase in the acetyl-CoA concentration, because the potential pathways for acetyl-CoA utilization (in the citrate or ketone-body synthesis) are limited. Conversely, the high capacity for ketone-body synthesis in colonocytes (Henning \& Hird, 1972) probably could explain a slightly higher capacity for glucose oxidation in colonocytes than in enterocytes (Kight \& Fleming, 1993). Similarly, the addition of $n$-butyrate moderately reduces the rate of glucose oxidation in pig colonocytes (Darcy-Vrillon et al. 1993).

Although the main fate of glucose in intestinal cells is always to generate $C_{3}$ products (pyruvate, lactate, alanine), this glycolytic activity can be altered by the nutritional conditions, for example during fasting in the rat (Butler et al. 1992; Newsholme \& Carrié, 1994) or immediately after a meal in the pig (Vaugelade et al. 1994). Hexokinase $(E C$ 2.7.1.1) and 6-phosphofructokinase $(E C 2.7 .1 .11)$ are identified as the limiting steps of the glycolytic pathway in intestinal cells (Newsholme \& Carrié, 1994). However, high activities of both enzymes prevail even in conditions of reduced glycolytic flux. This suggests that the flux through hexokinase and/or 6-phosphofructokinase could be controlled by the modulation of one or several factors, as suggested by Newsholme \& Carrié (1994). One possible mechanism of control could be the setting of a substrate cycle (glucose-glucose-6-phosphate cycle) due to the presence of an active glucose-6phosphatase (EC 3.1.3.9) in enterocytes (Bismut et al. 1993; Newsholme \& Carrié, 1994). Hexokinase activity which represents the sum of several isozyme activities (Srivastava et al. 1968) is inhibited by glucose-6-phosphate. A specific control of the flux through hexokinase by one of these isozyme activities and/or by variations of the glucose-6-phosphate concentration via the activity of 6-phosphofructokinase (Kellett et al. 1984) represent other possible mechanisms for the regulation of glucose metabolism.

Although the metabolic fate of lumen fatty acids in the intestinal cells is incorporation into triacylglycerol, contradictory results have been previously obtained concerning the role of plasma long-chain fatty acids (LCFA) as fuel substrates in enterocytes (Gangl \& Ockner, 1975; Windmueller \& Spaeth, 1978; Mansbach \& Dowell, 1992). Because high plasma LCFA levels generally prevail during fasting (Robinson \& Williamson, 1980), LCFA represent a potential source of energy in intestinal cells. However, recent observations in isolated pig enterocytes confirm that the rate of oleate oxidation determined in the presence of glucose and glutamine was limited even after a $3 \mathrm{~d}$ fasting period, representing only $10 \%$ of the amount of oleate metabolized (M. T. Morel, B. Darcy-Vrillon, F. Blachier and P. H. Duée, unpublished results). The primary regulatory step of LCFA oxidation in the liver is mitochondrial entry at the level of carnitine palmitoyltransferase I (EC 2.3.1.21; CPTI). The concentration of malonyl-CoA which acts as a potent inhibitor of CPTI and the sensitivity of CPTI to inhibition by malonyl-CoA represent predominant factors to explain the repartition of LCFA between 

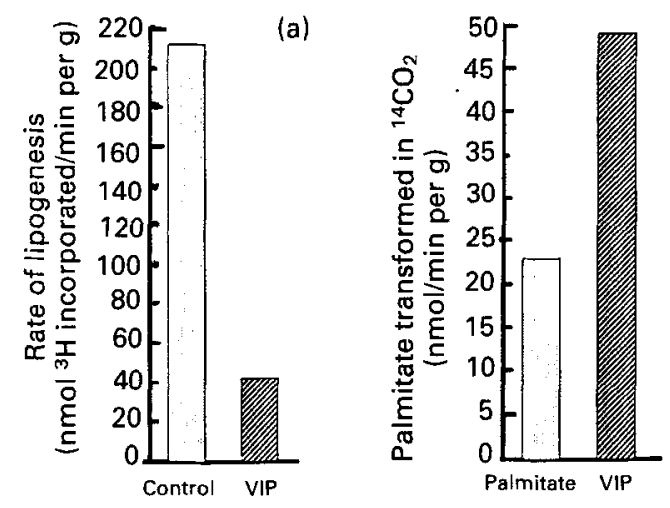

(b)

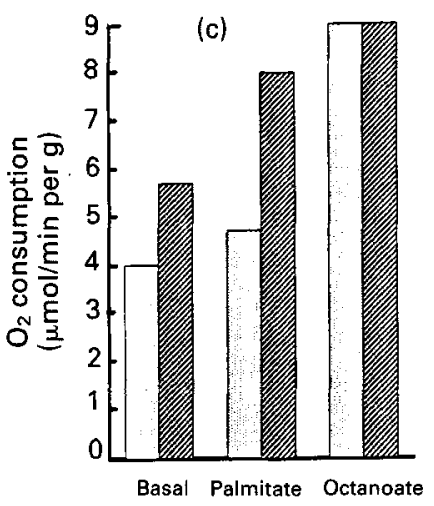

Fig. 3. Vasoactive intestinal peptide (VIP, 楼) effects on the rates of (a) lipogenesis, (b) palmitate oxidation and (c) oxygen consumption of isolated rat enterocytes. (Adapted from Vidal et al. 1988, 1989.)

oxidation and esterification (McGarry \& Foster, 1980). Metabolic data obtained by Vidal et al. (1988, 1989) suggest that such a control could operate in rat enterocytes. Indeed, unlike LCFA, the presence of octanoate which enters the mitochondrion by a carnitineindependent mechanism stimulates the rate of $\mathrm{O}_{2}$ consumption (Fig. 3). Although low in enterocytes, the rate of lipogenesis is inhibited by the addition of vasoactive intestinal peptide (VIP) which probably induces a lower malonyl-CoA concentration. Also, the rate of LCFA oxidation and the rate of $\mathrm{O}_{2}$ consumption are enhanced by VIP (Fig. 3). These findings also suggest that the hormonal milieu could promote the role of LCFA as fuel substrates. Finally, in the colon only, short-chain fatty acids produced by bacterial colonic fermentation are considered to be the major oxidative substrates (Roediger, 1982; Ardawi \& Newsholme, 1985). $\mathrm{CO}_{2}$ production accounts for about $40 \%$ of butyrate metabolism and total ketone-body production accounts for the remaining 60\% (DarcyVrillon et al. 1993; Clausen \& Mortensen, 1994). Thus, despite its capacity to utilize ketone bodies as fuel substrates as in other tissues (Robinson \& Williamson, 1980), the colon has the capacity for a net ketone-body production. The hydroxymethylglutarylCoA (HMG-CoA) synthase (EC 4.1.3.5) pathway would be the major route for ketogenesis from butyrate in the colon (Henning \& Hird, 1972). Even though the colonic epithelial cells possess the capacity to utilize acetate, propionate and butyrate, only butyrate suppresses the oxidation of the other short-chain fatty acids (Clausen \& Mortensen, 1994). Moreover, butyrate metabolism is not significantly affected by the presence of metabolic substrates from vascular origin, i.e. glucose and glutamine (Fleming et al. 1991; Darcy-Vrillon et al. 1993), which could explain its predominant role as a fuel substrate in the colon.

\section{ADAPTATIONS OF FUEL METABOLISM IN INTESTINAL CELLS}

Birth is accompanied by important modifications in several physiological functions and particularly dramatic changes of nutrition (Girard et al. 1992). The gastrointestinal tract 
becomes operative and undergoes marked structural and functional changes. Most of these changes occur at different times after birth, according to the species concerned (Darcy-Vrillon et al. 1994). The postnatal period is also associated with marked modifications in fuel metabolism of intestinal cells (Girard et al. 1992). Because milk is a high-fat diet, the question of the contributions of fatty acids as fuel substrates may arise. In the intestinal mucosa of sucking rats, fatty acids can be oxidized and even produce ketone bodies (Békési \& Williamson, 1990). The enzymes of the mitochondrial HMG-CoA pathway have been detected in the small intestine mucosa of the sucking rat. Moreover, the concentration of mitochondrial HMG-CoA synthase mRNA increases markedly in the rat jejunum after birth and remains elevated during the sucking period (Thumelin et al. 1993). Ketogenesis from endogenous substrates can be strongly inhibited by tetradecylglycidic acid, an inhibitor of LCFA oxidation, suggesting that LCFA are the main precursors for intestinal ketogenesis (Békési \& Williamson, 1990). When rats are weaned on a high-carbohydrate diet the ketogenic rate falls, as do the HMG-CoA synthase activity and the concentration of HMG-CoA synthase mRNA. Since the expression of HMG-CoA synthase gene could be reinduced when rats are weaned on a high-fat diet, the absorption of large amounts of fatty acids or hormonal changes could promote the transcription and/or the stabilization of intestinal HMG-CoA synthase mRNA (Thumelin et al. 1993).

In isolated mitochondria from rat small intestine, the production of ${ }^{14} \mathrm{CO}_{2}$ from $\left[1-{ }^{14} \mathrm{C}\right]$ palmitoyl-CoA is low during the sucking period and increases threefold after weaning (Kimura \& Warshaw, 1988). The removal of $\left[1-{ }^{14} \mathrm{C}\right]$ palmitoyl-CoA by mitochondria from adult and sucking rats is similar, although CPTI activity decreases slowly after weaning (see Girard et al. 1992). These data suggest that the capacity to oxidize LCFA remains fairly constant during the sucking period and after weaning, but that the fate of acetyl-CoA differs, reversing from ketone-body synthesis to oxidation in the tricarboxylic acid cycle.

Glutamine oxidation is high during the sucking period in rat intestinal tissue slices (Kimura, 1987) or isolated pig enterocytes (Darcy-Vrillon et al. 1994). In contrast, glucose and 3-hydroxybutyrate oxidation are lower during the sucking period than after weaning in the rat (Kimura, 1987). Glucose oxidation in rat intestinal tissue slices is

Table 2. Relative contribution of glucose and glutamine to ATP turnover in newborn pig enterocytes* (Adapted from Posho et al. 1994)

\begin{tabular}{lcc}
\hline & Birth & $2 \mathrm{~d}$ old $\dagger$ \\
\hline Total ATP turnover (nmol/min per 10 $0^{6}$ cells) & $26 \cdot 0$ & $42 \cdot 5$ \\
Percentage of ATP supported by: & 16 & 36 \\
Glucose metabolism & 9 & 11 \\
Oxidation & 7 & 25 \\
Glycolysis & 60 & 49 \\
Glutamine metabolism & 24 & 15 \\
Endogenous fuels & \\
\hline
\end{tabular}

* Total ATP turnover rate was estimated from $\mathrm{O}_{2}$ consumption in the presence of 2 mM-glucose and 2 mM-glutamine. Potential ATP production from glucose or glutamine was calculated on the basis of measured endproducts.

$\dagger$ Sucking animals in the post-absorptive state. 
100 -fold lower than the conversion of glucose to lactate. Since the rates of lactate and $\mathrm{CO}_{2}$ production from glucose slightly increase after weaning in the rat, these changes in glucose utilization could be explained by the concomitant variations in fatty acid metabolism (Kimura et al. 1984). However, in contrast to the rat situation, the rate of glycolysis is profoundly enhanced after birth in isolated pig enterocytes, while the rate at which glucose is completely oxidized remains constant (Darcy-Vrillon et al. 1994; Posho et al. 1994). Thus, the production of ATP from glucose through glycolysis is increased in sucking-pig enterocytes (Table 2). Besides a high glycolytic capacity, enterocytes isolated from sucking pigs also have the capacity to generate glucose from galactose or dihydroxyacetone (Darcy-Vrillon et al. 1994). Similarly, there is a sizeable generation of glucose from lactate in the intestinal mucosa of sucking rats (Hahn \& Wei-Ning, 1986). The emergence of a transient gluconeogenic pathway in sucking-pig enterocytes depends on colostrum ingestion and could be required for the synthesis of glycerol-3-phosphate needed for the high rate of intestinal re-esterification of fatty acids. Whether these metabolic adaptations in small intestinal cells are linked to parallel changes in both structure and function of enterocytes and could be controlled by hormonal changes during this period needs further investigation. The influence of ageing on glucose and glutamine metabolism has been investigated recently in rat jejunal cells (Fleming \& Kight, 1994). Compared with cells from young (4 months) fed animals, cells from fed aged ( 24 months) rats show lower $\mathrm{O}_{2}$ uptake in either the absence or presence of both substrates. Moreover, total $\mathrm{CO}_{2}$ production from glucose and glutamine is depressed, suggesting that intestinal fuel metabolism may require other additional substrates with ageing. In general, profound changes in intestinal fuel metabolism are observed in pathological states or when the hormonal milieu is substantially modified (Souba, 1991). Thus, intestinal glucose metabolism in the rat seems to be stimulated by insulin (Kellett et al. 1984) or inhibited by glucocorticoid treatment (Ardawi et al. 1988). Conversely, glucocorticoid administration increases the rate of glutamine utilization (Ardawi et al. 1988).

In enterocytes isolated from septic rats, rates of both glucose and glutamine utilization are decreased (Ardawi et al. 1990), suggesting that the response to sepsis induces different metabolic responses in the gut compared with other tissues. Finally, in streptozotocin-diabetic rats, glucose and glutamine metabolism, also, are profoundly altered: an increased rate of glucose metabolism parallels a lower rate of glutamine utilization (Anderson, 1974; Watford et al. 1987; Ardawi, 1988). Moreover, during prolonged diabetes, a more important role for ketone bodies and fatty acids as fuel substrates becomes evident (Watford et al. 1987; Ardawi, 1988). Again, the mechanism for such an adaptation remains to be elucidated.

\section{CONCLUSION}

The main functions of the gastrointestinal mucosa are digestion and nutrient transport as well as defence against noxious substances. The gut is not an inert tube, because its mucosa displays a central role in the whole-body metabolism. This high metabolic activity of the mucosa can be modulated according to the nutritional, physiological or pathological conditions. Additional information is needed on the role of hormonal pattern on fuel selection in intestinal cells, and also on the relationship between this metabolic activity and the function and integrity of the intestine. 


\section{REFERENCES}

Anderson, J. W. (1974). Glucose metabolism in jejunal mucosa of fed, fasted, and streptozotocin diabetic rats. American Journal of Physiology 226, 226-229.

Ardawi, M. S. M. (1988). Glutamine and ketone-body metabolism in the gut of streptozotocin-diabetic rats. Biochemical Journal 249, 565-572.

Ardawi, M. S. M., Jamal, Y. S., Ashy, A. A., Nasr, H. \& Newsholme, E. A. (1990). Glucose and glutamine metabolism in the small intestine of septic rats. Journal of Laboratory and Clinical Medicine 115, 660-668.

Ardawi, M. S. M., Majzoub, M. F. \& Newsholme, E. A. (1988). Effect of glucocorticoid treatment on glucose and glutamine metabolism by the small intestine of the rat. Clinical Science 75, 93-100.

Ardawi, M. S. M. \& Newsholme, E. A. (1985). Fuel utilization in colonocytes of the rat. Biochemical Journal 231, 713-719.

Ashy, A. A. \& Ardawi, M. S. M. (1988). Glucose, glutamine, and ketone-body metabolism in human enterocytes. Metabolism 37, 602-609.

Békési, A. \& Williamson, D. H. (1990). An explanation for ketogenesis by the intestine of the suckling rat: the presence of an active hydroxymethylglutaryl-coenzyme A pathway. Biology of the Neonate 58, 160-165.

Bismut, H., Hers, H. G. \& Van Schaftingen, E. (1993). Conversion of fructose to glucose in the rabbit small intestine. European Journal of Biochemistry 213, 721-726.

Blachier, F., Darcy-Vrillon, B., Sener, A., Duée, P. H. \& Malaisse, W. J. (1991a). Arginine metabolism in rat enterocytes. Biochimica et Biophysica Acta 1092, 304-310.

Blachier, F., M'Rabet-Touil, H., Darcy-Vrillon, B., Posho, L. \& Duée, P. H. (1991b). Stimulation by $\mathrm{D}$-glucose of the direct conversion of arginine to citrulline in enterocytes isolated from pig jejunum. Biochemical and Biophysical Research Communications 117, 1171-1177.

Brundin, T. \& Wahren, J. (1991). Influence of a mixed meal on splanchnic and interscapular energy expenditure in humans. American Journal of Physiology 260, E232-E237.

Butler, R. N., Goland, G., Jarrett, I. G., Fettman, M. J. \& Roberts-Thomson, I. C. (1992). Glucose metabolism in proliferating epithelial cells from the rat colon. Comparative Biochemistry and Physiology 101B, 573-576.

Clausen, M. R. \& Mortensen, P. B. (1994). Kinetic studies on the metabolism of short-chain fatty acids and glucose by isolated rat colonocytes. Gastroenterology 106, 423-432.

Darcy-Vrillon, B., Morel, M. T., Cherbuy, C., Bernard, F., Posho, L., Blachier, F., Meslin, J. C. \& Duée, P. H. (1993). Metabolic characteristics of pig colonocytes after adaptation to a high fiber diet. Journal of Nutrition 123, 234-243.

Darcy-Vrillon, B., Posho, L., Morel, M. T., Bernard, F., Blachier, F., Meslin, J. C. \& Duée, P. H. (1994). Glucose, galactose, and glutamine metabolism in pig isolated enterocytes during development. Pediatric Research 36, 175-181.

Evered, D. F. \& Masola, B. (1984). The oxidation of glutamine and glutamate in relation to anion transport in enterocyte mitochondria. Biochemical Journal 218, 449-458.

Firmansyah, A., Penn, D. \& Lebenthal, E. (1989). Isolated colonocyte metabolism of glucose, glutamine, $n$-butyrate, and $\beta$-hydroxybutyrate in malnutrition. Gastroenterology 97, 622-629.

Fleming, S. E., Fitch, M. D., Devris, S., Liu, M. L. \& Kight, C. (1991). Nutrient utilization by cells isolated from rat jejunum, cecum and colon. Journal of Nutrition 121, 869-878.

Fleming, S. E. \& Kight, C. E. (1994). The TCA cycle as an oxidative and synthetic pathway is suppressed with aging in jejunal epithelial cells. Canadian Journal of Physiology and Pharmacology 72, 266-274.

Gangl, A. \& Ockner, R. K. (1975). Intestinal metabolism of plasma free fatty acids. Intracellular compartmentation and mechanisms of control. Journal of Clinical Investigation 55, 803-813.

Girard, J., Ferré, P., Pégorier, J. P. \& Duée, P. H. (1992). Adaptations of glucose and fatty acid metabolism during perinatal period and suckling-weaning transition. Physiological Reviews 72, 507-562.

Granger, H. J. \& Norris, C. P. (1980). Intrinsic regulation of intestinal oxygenation in the anaesthetized dog. American Journal of Physiology 238, H836-H843.

Hahn, P. \& Wei-Ning, H. (1986). Gluconeogenesis from lactate in the small intestinal mucosa of suckling rats. Pediatric Research 20, 1321-1323.

Hanson, P. J. \& Parsons, D. S. (1977). Metabolism and transport of glutamine and glucose in vascularly perfused small intestine of the rat. Biochemical Journal 166, 509-519.

Hanson, P. J. \& Parsons, D. S. (1980). The interrelationship between glutamine and alanine in the intestine. Biochemical Society Transactions 8, 506-509. 
Henning, S. J. \& Hird, F. J. R. (1972). Ketogenesis from butyrate and acetate by the caecum and the colon of rabbits. Biochemical Journal 130, 785-790.

Jungas, R. L., Halperin, M. L. \& Brosnan, J. T. (1992). Quantitative analysis of amino acid oxidation and related gluconeogenesis in humans. Physiological Reviews 72, 419-448.

Kellett, G. L., Jamal, A., Robertson, J. P. \& Wollen, N. (1984). The acute regulation of glucose absorption, transport and metabolism in rat small intestine by insulin in vivo. Biochemical Journal 219, 1027-1035.

Kight, C. E. \& Fleming, S. E. (1993). Nutrient oxidation by rat intestinal epithelial cells is concentration dependent. Journal of Nutrition 123, 876-882.

Kimura, R. E. (1987). Glutamine oxidation by developing rat small intestine. Pediatric Research 21, $214-217$.

Kimura, R. E., Thulin, G. \& Warshaw, J. B. (1984). The effect of ketone bodies and fatty acid on intestinal glucose metabolism during development. Pediatric Research 18, 575-579.

Kimura, R. E. \& Warshaw, J. B. (1988). Control of fatty acid oxidation by intramitochondrial [NADH]/ $[\mathrm{NAD}+]$ in developing rat small intestine. Pediatric Research 23, 262-265.

Lamers, J. M. J. \& Hülsmann, W. C. (1974). The effects of fatty acids on oxidative decarboxylation of pyruvate in rat small intestine. Biochimica et Biophysica Acta 343, 215-225.

McGarry, J. D. \& Foster, D. W. (1980). Regulation of hepatic fatty acid oxidation and ketone body production, Annual Review of Biochemistry 49, 395-420.

Mallet, R. T., Jackson, M. J. \& Kelleher, J. K. (1986a). Jejunal epithelial glucose metabolism: effects of Na+ replacement. American Journal of Physiology 251, C803-C809.

Mallet, R. T., Kelleher, J. K. \& Jackson, M. J. (1986b). Substrate metabolism of isolated jejunal epithelium: conservation of three-carbon units. American Journal of Physiology 250, C191-C198.

Mansbach, C. M. II \& Dowell, R. F. (1992). Uptake and metabolism of circulating fatty acids by rat intestine. American Journal of Physiology 263, G927-G933.

Newsholme, E. A. \& Carrié, A. L. (1994). Quantitative aspects of glucose and glutamine metabolism by intestinal cells. Gut, Suppl. 1, S13-S17.

Pinkus, L. M. \& Windmueller, H. G. (1977). Phosphate-dependent glutaminase of small intestine: localization and role in intestinal glutamine metabolism. Archives of Biochemistry and Biophysics 182, 506-517.

Posho, L., Darcy-Vrillon, B., Blachier, F. \& Duée, P. H. (1994). The contribution of glucose and glutamine to energy metabolism in newborn pig enterocytes. Journal of Nutritional Biochemistry 5, 284-290.

Rhoads, J. M., Keku, E. O., Woodard, J. P., Bangdiwala, S. I., Lecce, J. G. \& Gatzy, J. T. (1992). L-Glutamine with $\mathrm{D}$-glucose stimulates oxidative metabolism and $\mathrm{NaCl}$ absorption in piglet jejunum. American Journal of Physiology 263, G960-G966.

Robinson, A. M. \& Williamson, D. H. (1980). Physiological roles of ketone bodies as substrates and signals in mammalian tissues. Physiological Reviews 60, 143-187.

Roediger, W. E. W. (1982). Utilization of nutrients by isolated epithelial cells of the rat colon. Gastroenterology 83, 424-429.

Sit, S. S. \& Chou, C. C. (1984). Time course of jejunal blood flow, $\mathrm{O}_{2}$ uptake, and $\mathrm{O}_{2}$ extraction during nutrient absorption. American Journal of Physiology 247, H395-H402.

Souba, W. W. (1991). Glutamine: a key substrate for the splanchnic bed. Annual Review of Nutrition 11, 285-308.

Srivastava, L. M., Shakespeare, P. \& Hübscher, G. (1968). Glucose metabolism in the mucosa of the small intestine. Biochemical Journal 109, 35-42.

Thumelin, S., Forestier, M., Girard, J. \& Pégorier, J. P. (1993). Developmental changes in mitochondrial 3-hydroxy-3-methylglutaryl-CoA synthase gene expression in rat liver, intestine and kidney. Biochemical Journal 292, 493-496.

Vaugelade, P., Posho, L., Darcy-Vrillon, B., Bernard, F., Morel, M. T. \& Duée, P. H. (1994). Intestinal oxygen uptake and glucose metabolism during nutrient absorption in the pig. Proceedings of the Society for Experimental Biology and Medicine 207, 309-316.

Vidal, H., Beylot, M., Comte, B., Vega, F. \& Riou, J. P. (1989). Vasoactive intestinal peptide stimulates long-chain fatty acid oxidation and inhibits acetyl-coenzyme $A$ carboxylase activity in isolated rat enterocytes. Journal of Biological Chemistry 264, 4901-4906.

Vidal, H., Comte, B., Beylot, M. \& Riou, J. P. (1988). Inhibition of glucose oxidation by vasoactive intestinal peptide in isolated rat enterocytes. Journal of Biological Chemistry 263, 9206-9211.

Watford, M. (1994). Glutamine metabolism in rat small intestine: synthesis of three-carbon products in isolated enterocytes. Biochimica et Biophysica Acta 1200, 73-78.

Watford, M., Erbelding, E. J. \& Smith, E. M. (1987). The regulation of glutamine and ketone-body metabolism in the small intestine of the long-term (40 day) streptozotocin-diabetic rat. Biochemical Journal 242, 61-68. 
Watford, M., Lund, P. \& Krebs, H. A. (1979). Isolation and metabolic characteristics of rat and chicken enterocytes. Biochemical Journal 178, 589-596.

Watford, M. \& Tatro, A. V. (1989). Phosphoenolpyruvate carboxykinase of rat small intestine: distribution and regulation of activity and mRNA levels. Journal of Nutrition 119, 268-272.

Weber, F. L. Jr, Veach, G. \& Friedman, D. W. (1982). Stimulation of ammonia production from glutamine by intraluminal glucose in small intestine of dogs. American Journal of Physiology 242, G552-G557.

Windmueller, H. G. \& Spaeth, A. E. (1974). Uptake and metabolism of plasma glutamine by the small intestine. Journal of Biological Chemistry 249, 5070-5079.

Windmueller, H. G. \& Spaeth, A. E. (1978). Identification of ketone bodies and glutamine as the major respiratory fuels in vivo for postabsorptive rat small intestine. Journal of Biological Chemistry 253, 69-76.

Windmueller, H. G. \& Spaeth, A. E. (1980). Respiratory fuels and nitrogen metabolism in vivo in small intestine of fed rats. Journal of Biological Chemistry 255, 107-112.

Yen, J. T., Nienaber, J. A., Hill, D. A. \& Pond, W. G. (1989). Oxygen consumption by portal vein-drained organs and by whole animal in conscious growing swine. Proceedings of the Society for Experimental Biology and Medicine 190, 393-398. 